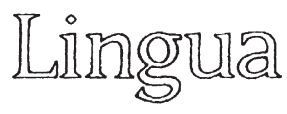

Lingua 122 (2012) 1165-1181

www.elsevier.com/locate/lingua

\title{
Stress as a proclitic in Modern Greek
}

\author{
Marc van Oostendorp \\ Meertens Instituut, KNAW and Leiden University, Netherlands \\ Received 22 April 2011; received in revised form 19 May 2012; accepted 19 May 2012 \\ Available online 3 July 2012
}

\begin{abstract}
Virtually all past tense forms of the Greek verb are characterised by antepenultimate stress. This fact is problematic for standard views of the prosody-morphology interface in Greek, for which it is usually assumed that inflectional categories cannot uniquely determine the stress pattern of a word. Furthermore, antepenultimate stress is not otherwise known as an effect of affixal morphology. It is proposed that we can understand the behaviour of past tense if we assume that past tense is a proclitic consisting of a segmentally empty foot only. It is shown how this analysis fits in with our current morphosyntactic and phonological knowledge of the structure of the Greek verb.
\end{abstract}

(C) 2012 Elsevier B.V. All rights reserved.

Keywords: Phonology; Morphosyntax; Stress; Modern Greek

\section{Introduction}

Past tense forms of verbs in Modern Greek, such as the imperfective and the aorist, are characterised by having antepenultimate stress ${ }^{1}$ :

(1) yrafo 'I write'

\begin{tabular}{|c|c|c|}
\hline resent & Imperfective & Aorist \\
\hline rráf-c & é-yraf-a & é-yr \\
\hline ráf-is & af-es & é-yra \\
\hline rráf-i & é-yraf-e & é-yraps-e \\
\hline ráf-ume & yráf-ame & yráps \\
\hline yráf-ete & yráf-ate & yráps-ate \\
\hline rráf-un(e) & yráf-ane / é-yraf-an & yráps-ane / é-yraps-an \\
\hline
\end{tabular}

This seemingly simple observation causes a number of serious problems for current theories of the prosodymorphology interface, which extend beyond the analysis of Modern Greek proper. In the first place, cases where the exponence of inflection is accentual are rare in the literature, ${ }^{2}$ and the Greek case raises the question whether and how 'floating' word stress can be represented as an independent inflectional morpheme. Secondly, previous analyses of Modern Greek stress, mostly based on nouns, have suggested that lexical stress on roots always overrides lexical stress on inflectional suffixes (see Revithiadou, 1999, 2007; Burzio and Tantalou, 2006; Apoussidou, 2003, for a variety of views). Yet in the case of the past tense, inflectional stress must be strong enough to override all root specifications, since

\footnotetext{
E-mail address: marc.van.oostendorp@meertens.knaw.nl.

1 Acknowledgements: Thanks are due to Björn Köhnlein, Peter Jurgec, Anthi Revithiadou, Nina Topintzi for comments. All usual disclaimers apply.

${ }^{2}$ A case in point may be Russian; but like Greek, the effects seem to be restricted to verbs. See e.g. Melvold (1990).
} 
all verbal roots show this behaviour for all persons and numbers. Finally, the stress triggered by the past tense morpheme is of an interesting nature: it is on the antepenultimate syllable, and if such a syllable is missing, it forces it into existence, by triggering an 'augment' e-. No other phonological or morphological rule in Modern Greek has this force.

In this paper, I argue that these puzzles can be solved by assuming that the phonological exponence of the functional head ([Past]) Tense in Greek is a floating foot which syntactically precedes the stem. Empirically, this paper adds a new domain to the study of prosody-morphology interaction, since the details of Greek verbal stress have not been taken into account in the literature so far. Theoretically, I concentrate on two representational implications of this proposal, both from the point of view of phonology - what does a floating stress marker look like? - and from the point of view of the phonology-syntax interface - what does the syntactic structure look like, and how is it mirrored in the phonology?

An important aim of this paper is to show that a principled analysis of stress in the past tense is possible in Greek, based on the following principles of the interface between phonology and morphology.

First, morphology is additive and morpheme-based. That is to say, we expect morphological complexity to be reflected in the phonology: if word $A$ consists of stem $B$ and affix $C$, we expect $A$ to be more complex than $B$ phonologically.

Secondly, morphological structure is also otherwise reflected in the phonology. That is to say, morphological headedness is reflected in phonological headedness and morphological boundaries are reflected in phonological boundaries.

These principles seem to work for Greek nouns, as will be outlined in the next section; although the data on verbs look problematic at first sight, we will argue that they actually fit into the picture very nicely in the sections that follow.

\section{Lexical stress in Greek}

Greek word stress has been the topic of quite some research in the past few years (Malikouti-Drachman and Drachman, 1989; Revithiadou, 1999, 2007; Drachman and Malikouti-Drachman, 1999; Burzio and Tantalou, 2006; Apoussidou, 2003). Although there is no absolute convergence on the precise analysis, it is safe to extract a few generalisations from the literature, which has thus far concentrated on stress in nouns.

There is consensus that stress is lexical in Greek, in the sense that it is largely unpredictable by phonological criteria such as syllable weight or vowel quality, and dependent on lexical specification instead. In particular, some words have stress on the final syllable, some on the penultimate, and some on the antepenultimate syllable ${ }^{3}$ :
a. ayorá 'market'
b. stafiða 'raisin'
c. tálasa 'sea'

In this section, I will briefly discuss both the phonology and the morphology of the Greek accentual system in nouns. I cannot go into all the details, but we need this background information, since most views of Greek stress now are based on stress in nouns.

\subsection{The phonology of nominal stress}

There is one important observation on the lexical assignment of stress, in all categories of Greek words: it is restricted by a three-syllable window (at least in the standard language, which is discussed here). Stress can fall on any of the last three syllables, but not on any other syllable of the word.

There are two types of evidence for this generalisation: static evidence from the distribution in the lexicon, and dynamic evidence from stress shift.

As to the former, there are no words such as *[sérvitoros] (cf. [servitóros] 'waiter') in the native lexicon. As to the latter, clitics induce what is called 'enclisis of stress', when added to words with antepenultimate stress (Nespor and Vogel, 1986; Holton et al., 2006):

(3) a. yónðola 'gondola' $\rightarrow$ yónðolá-mu 'my gondola'

b. o yítonas 'the neighbour' $\rightarrow$ o yítonáz mas 'our neighbour'

c. apénandi 'opposite' $\rightarrow$ apénandí mas 'opposite us'

d. xárise 'give' (IMP) $\rightarrow$ xárisé mu to 'give it to me'

e. (cf. stafíða 'raisin' $\rightarrow$ stafíða-mu 'my raisin' without 'enclisis of stress')

\footnotetext{
${ }^{3}$ In this paper, I give transcriptions in IPA.
} 
As can be seen in this example, 'enclisis of stress' does not mean that the stress is completely shifted; rather, the original stress is maintained, and an extra stress is added on the final two syllables of the word. Holton et al. (2006) note however that "of the two stresses the second one, the stress derived by enclisis, is stronger", so that in some clear sense 'word stress' is shifted, and the original primary stress is retained as a secondary stress. Further, 'real' stress shift is seen in the inflection of certain classes of nouns, which have their basic stress on the antepenultimate syllable, and will move this if an inflectional ending adds an extra syllable:

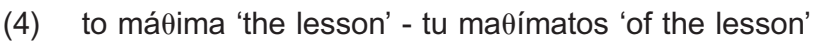

We will not go into the precise mechanisms of enclisis of stress and stress shift; we merely use them as indications as to the strength of the three-syllable window in Modern Greek prosody.

These are the basics of the Greek stress system. In terms of Optimality Theory, in which we will couch our analysis here, we can derive this rather simple system from a number of constraints: in particular a constraint enforcing the threesyllable window and a constraint on preservation of underlying foot structure. The former dominates the latter, hence (trivially) we never find stress outside the window ${ }^{4}$ :

(5) a. 3r: Stress should be on one of the

last three syllables of the word.

b. FAITH-STRESS: Underlying stress

should be preserved.

c. $3 \sigma \gg$ FAITH-STRESS

d.

\begin{tabular}{|c|c|c|}
\hline má $\operatorname{\theta imat}+o s$ & $3 \sigma$ & FAITH-STRESS \\
\hline 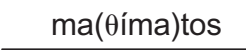 & & 1 \\
\hline a. $\sim$ má $\theta i m a t o s$ & $1 \mathrm{~W}$ & 0 \\
\hline
\end{tabular}

A reasonable question to ask is how underlying stress is represented. This can be done in several ways, but from the discussion below it will follow that we assume that metrical feet are underlying and faithfulness constraints demand their preservation.

Stress shift in cases like this is to the proparoxytone. This is one reason why it is sometimes assumed that antepenultimate stress is the default in Modern Greek. ${ }^{5}$ There are independent arguments for this position. For instance, in (certain types of) compounds, underlying stress of both roots is removed, and replaced by stress on the antepenultimate syllable (Nespor and Ralli, 1994, 1996; Ralli, 1997; Revithiadou, 1997; Nikolou, 2005):

(6) a. kuzinomáxero 'kitchen knife' (from kuzína 'kitchen' and maxéri 'knife')

b. lemonóðasos 'lemon tree forest' (from lemóni 'lemon tree' and ðásos 'forest')

Although there are a few morphological differences between the forms in (6a) and those in (6b), involving e.g. the ending of the whole form, stress ends up on the antepenultimate syllable in both cases. Since this stress does not have any clear lexical origin - it does not correspond to the underlying stress of any of the compounding roots -, it seems reasonable to assume that it is a default.

The result of stress shift in (4) is another instance of the default nature of antepenultimate stress: if stress shifts at all - if we are ever unfaithful to the underlying stress -, apparently it moves to the antepenultimate syllable. We may assume that this default arises due to the interaction of two well-formedness constraints, one requiring Greek feet to be trochaic, and one requiring the last syllable of the word to be unfooted.

\footnotetext{
${ }^{4}$ I would not claim that $3 \sigma$ is a likely candidate for our universal set of constraints Con. Rather, its effects should be derived from some configuration of other constraints on the right-alignment of the stressed (trochaic) foot, and the possibility of having exactly one non-footed syllable at the right edge. However, in order not to complicate the tableaux too heavily, and since the phonological analysis of stress functions merely as the background to our claims on the prosody-morphology interface, I have decided to use this cover constraint.

${ }^{5}$ Protopapas et al. (2006) argue that penultimate, rather than antepenultimate acts as a default in reading tasks in Greek (mistakes on unknown words are made towards the penult). Further, an anonymous reviewer suggests that there are also stress shifts towards the penult, viz. in forms

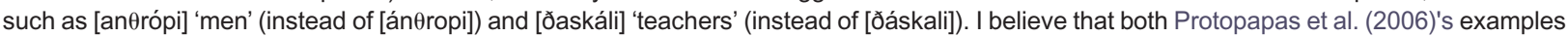
and the reviewer's are less revealing about the grammatical nature of these things, as they concern shifts in individual items rather than systematic ones. It is possible that penultimate stress is the most frequent one, and hence acts as an attractor in cases were stress is unknown.
} 
(7) a. TROCHEE: Feet are left-headed.

b. NonFin: The main-stressed foot should not be final in the word.

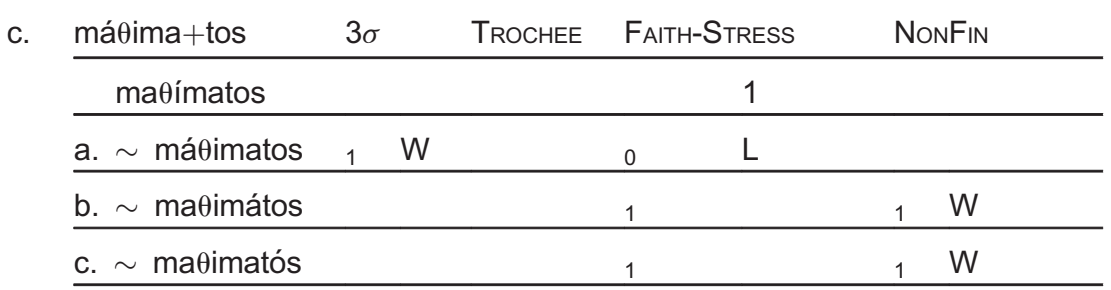

We will assume that the constraint TROCHEE is inviolable in the language, since languages which mix trochees and iambs are scarce, and there is no evidence that Modern Greek is of this type. For this reason, we will also not consider any candidates with iambs in the tableaux which follow. However, we do need to establish a ranking FAITH-STRESS》NONFIN, since lexical specification can cause stress to be penultimate or final, as we have observed in (1). For the sake of the argument, let us assume for a moment that a stem like stafída 'grape' does not have internal morphological structure. It does have a stress marking overriding the default:

(8)

\begin{tabular}{|c|c|c|c|}
\hline stafíða & $3 \sigma$ & FAITH-STRESS & NonFIN \\
\hline stafiða & & & 1 \\
\hline a. $\sim$ stáfiða & & W & $\mathrm{L}$ \\
\hline b. $\sim$ stafiðá & & $1 \quad W$ & 1 \\
\hline
\end{tabular}

Before we move to the influence of morphology on the calculation of stress, we need to say a few words about the constraint FAITH-STRESS. What exactly is the phonological object we are being faithful to? Logically speaking, there are two options for the representation of underlying stress: we can either picture it autosegmentally as 'a grid mark which is projected onto the stress plane as an idiosyncratic property of a vocalic peak' (Revithiadou, 2007) as in (9a), or we can picture it in a metrical way as an underlying foot as in (9b):

(9)
a. sta fi ða
$\mathrm{Ft}$
b. sta fi ða

Which representation we prefer depends on many other assumptions we make. However, notice that if stress is represented by feet on the surface, as is standardly assumed, the principle Richness of the Base (RotB) forces us at least to take the option of underlying feet seriously.

Such underlying feet furthermore have the advantage of correctly predicting locality, as Revithiadou (2007) points out. In particular, so-called preaccenting suffixes put stress on the syllable immediately preceding them, i.e. the last syllable of the root (except if the root has a conflicting specification; see below). An example of this is masculine and neuter genitive

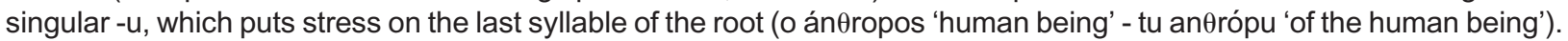
Since the accent is not realized on the suffixes themselves, it is plausible to view it as floating in these cases. It is not clear why a floating accentual marker would always be realized locally, on the root-final syllable. It is easier to account for this if these suffixes are marked as the tails of feet, which have to be immediately preceded by a head.

\section{Representation of preaccenting suffixes}
a. u
$\mathrm{Ft}$
b. $\emptyset \mathrm{u}$ 
Revithiadou (2007) rejects the option of floating feet, because it makes it difficult to represent pre-accenting and postaccenting morphemes in a uniform way. We will return to this in section 4.1. For now, we will ignore this problem and assume underlying feet.

\subsection{The morphology of Greek nominal stress}

Let us return for a while to (2), repeated here for convenience:

(2) a. ayorá 'market'

b. stafíða 'raisin'

c. $\quad$ álasa 'sea'

We have now established that the differences between these three forms are due to differences in lexical marking. In particular, the form stafída will have an underlying trochaic foot with a head on the penultimate syllable. How about the other two forms?

The issue with the first case, agorá, is that stress is on the final -a which is assumed not to be part of the root itself, but rather inflectional in nature (expressing feminine nominative singular in this case). However, the stress in this position is clearly a property of the root, and not of the suffix. Next to being marked for bearing stress on a specific syllable, roots can apparently also be postaccenting. In this case, they force stress on the immediately following syllable, which in this case contains a suffix. We will again postpone discussion of the representation of postaccentuation to section 4.1; for now, we assume it is some marking which will also be sensitive to FAITH-STRESS. Post-accenting stems are sometimes marked by -' $\square$, a notational convention we will follow here as well:

\begin{tabular}{|c|c|c|c|c|c|c|}
\hline ayoŕ $\square+a$ & $3 \sigma$ & \multicolumn{2}{|c|}{ FAITH-STRESS } & TROCHEE & & NFIN \\
\hline ayorá & & & & & & 1 \\
\hline a. $\sim$ áyora & & 1 & W & & 0 & $\mathrm{~L}$ \\
\hline b. $\sim$ ayóra & & 1 & W & & 0 & $\mathrm{~L}$ \\
\hline
\end{tabular}

The issue with proparoxytone stems such as the one in (2c) is that they can derive from two sources. Since antepenultimate stress is the default, roots without any stress specifications will get this stress pattern as well as those which have an underlying marking on the antepenultimate syllable. Interestingly, traditional Greek linguistics distinguishes between two types of proparoxytones: one in which the stress moves within the nominal paradigm, and one in which it does not ${ }^{6}$ :

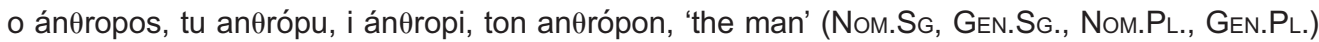

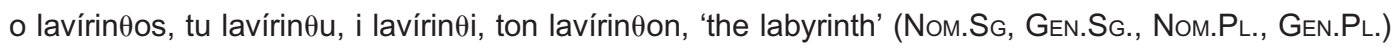

We can identify paradigms such as those in (13) with an underlying stress marking on the root, which is always realized. Paradigms in (12) on the other hand are examples of roots without a stress marking; if the suffix also does not have a stress marking (such as the nominative suffixes), we get default stress. But if the inflectional suffix is marked (as is the case for the genitives), this stress decides.

We thus see that in this system, which is mostly due to Revithiadou (1999), there are three different types of roots: (i) unaccented, (ii) accented, (iii) post-accenting. What about other affixes? Different from e.g. Germanic languages like English, Greek requires all lexical words to consist of more than one morpheme: at least a root and a desinence, denoting case, gender and lexical class in the case of nouns. Since all morphemes can be marked or unmarked for underlying stress, and since every word will contain exactly one stress, we need a calculus on how to derive this one lexical stress from the underlying specifications. Most of the work on Greek stress has been devoted to establish this calculus. In particular, if several morphemes have underlying stress, how do we decide which of those underlying markings we want to preserve?

\footnotetext{
${ }^{6}$ The form in (13) can actually also have the pattern of that in (12), at least for some speakers.
} 
In order to be able to talk about this, we need a reasonably articulated theory of morphology. We will base our analysis on the following assumptions:

1. Morphology is morpheme-based.

2. There are no morphological diacritics.

3. There is no stipulated lexical difference between roots and affixes.

4. Morphological structures are characterised by headedness, and inflectional affixes are no heads.

With respect to the structure of morphology (Assumption 1), we adopt a classical Items-and-Arrangement view (Hockett, 1958), and assume that words consist of morphemes which are arranged in some hierarchical structure. Phonology operates on such morphological trees and interprets them in terms of its own set of primitives and possible structural arrangements.

Further (Assumption 2), we assume that there are no morphological diacritics: phonological behaviour is represented in terms of underlying phonological structure, and not in terms of any abstract morphological property or feature. In particular, unpredictable stress is represented in terms of underlying stress marking (and Faithfulness constraints operating on these markings) rather than by way of some morphological class marking.

RotB furthermore forces us to assume that stress can be present on any syllable in inputs, and also be completely absent. We have seen in the preceding section how this seems to hold for roots. However, in principle, it should apply to all morphemes (Assumption 3): roots, derivational and inflectional affixes. We will see that this means that every morpheme $M$ should come in one of three flavours: (i) No marking; (ii) Marking on some syllable of $M$, or (iii) Marking for stress but not on $M$ (pre-accenting or post-accenting).

Since we do not allow morphological diacritics, differences between roots and affixes should follow from differences in structure. If morphemes $M_{1}$ and $M_{2}$, both marked for stress, are combined, a conflict between faithfulness constraints arises: we cannot have both underlying stress markings surface, since there is only one (primary) stress in the Greek word. In Revithiadou $(1999,2007)$ 's proposal, which we will follow here, the conflict is resolved by headedness (Assumption 4): the morphological head of $\left[M_{1} M_{2}\right]$ decides. Furthermore, following a classical distinction in morphology, derivational affixes are heads of words (since they determine the morphosyntactic category), inflectional affixes are not (Selkirk, 1982). ${ }^{7}$

If derivational suffixes are morphological heads, they will always win: their marking will surface, even if it conflicts with the marking on the root. Revithiadou (1999) cites diminutive suffixes as an example. This suffix decides gender, and hence it counts as a head. If -áki- (which is one of the shapes the diminutive can take) combines with a root like kubár, which has a stress marking on its final syllable, it causes deletion of the stem stress:

\begin{tabular}{|c|c|c|c|}
\hline $\begin{array}{l}\text { to prósopo } \\
\text { 'the face' (N.) } \\
\text { o kubáros } \\
\text { 'the best man' (M.) }\end{array}$ & $\begin{array}{l}\text { +áki } \\
\text { DıM. (N.) } \\
+ \text { áki } \\
\text { DıM. (N.) }\end{array}$ & $\begin{array}{l}\rightarrow \\
\rightarrow\end{array}$ & $\begin{array}{l}\text { to prosopáci } \\
\text { 'the face' (Dıм., N.) } \\
\text { to kubaráci } \\
\text { 'the best man' (DıM., N.) }\end{array}$ \\
\hline
\end{tabular}

-áki is an example of a stressed derivational suffix, and many derivational suffixes are stressed: 20 out of the list of 27 derivational suffixes in Holton et al. (2006) are marked for being stressed, 3 are marked for being prestressing (e.g. nominalizing -tita: epísimos 'formal' $\rightarrow$ episimótita 'formality'); 4 have no stress marking, but none of these 4 are without their complications. ${ }^{8}$

Inflectional suffixes on the other hand are not heads; they do not determine the category or the gender of the noun. Hence they always lose. The genitive singular, for instance, is marked for being preaccenting, but it only surfaces as such if the stem allows it, i.e. if the stress specification of the stem does not conflict with it:

$$
\begin{aligned}
& \text { klívan } \quad+\square \dot{u} \rightarrow \text { klívanu } \\
& \text { 'kiln' (M.) GEN. 'the kiln' (GEN., SG., M.) }
\end{aligned}
$$

\footnotetext{
${ }^{7}$ Notice that modern minimalism and Distributed Morphology make a slightly different assumption. In those frameworks, inflectional heads are considered heads of the overall structure; under such assumptions one would still need to distinguish between such 'heads' and the categorychanging 'heads' of derivational morphology; that is the relevant distinction for our purposes.

${ }^{8}$ The first of these is augmentative -a, which seems to be added mostly to stems in -al-, with final stress: kefáli 'head'/kefála 'big head', kutáli 'spoon'/kutála 'big spoon'. It is hard to draw any conclusions from this about the stress specification of the suffix; a reviewer also notes that -a is prestressing in e.g. kutí 'box' - kúta. The second suffix is adjectivizing -imos and the third and fourth are nominalizing -ma and -si/ksi/psi. All of these go with verbs and seem to trigger antepenultimate stress, in a way which will need more extensive research: eksáyo $\rightarrow$ eksayóyimos 'exportable', ðiavázo $\rightarrow$ điávazma 'reading', ispráto $\rightarrow$ íspraksi 'collection of money'.
} 
The following table lays out the way in which conflicts between roots and inflectional suffixes are resolved:

\begin{tabular}{|c|c|c|}
\hline & $\begin{array}{l}\text { Unmarked suffix } \\
\text {-los/ (Nom. SG.) }\end{array}$ & $\begin{array}{l}\text { Marked (preaccenting) suffix } \\
-/ \square \dot{u} /(\text { (GEN. sG.) }\end{array}$ \\
\hline $\begin{array}{l}\text { Unmarked root } \\
\text { (/an } \theta \text { rop/- 'man') }\end{array}$ & $\begin{array}{l}\text { default stress } \\
\text { [án日ropos] }\end{array}$ & $\begin{array}{l}\text { suffix decides } \\
\text { [an } \theta \text { rópu] }\end{array}$ \\
\hline $\begin{array}{l}\text { Marked root } \\
\text { (/klívan/- 'kiln') }\end{array}$ & $\begin{array}{l}\text { root decides } \\
\text { [klívanos] }\end{array}$ & $\begin{array}{l}\text { root decides } \\
\text { [klívanu] }\end{array}$ \\
\hline $\begin{array}{l}\text { Marked root } \\
\text { (/kubár/- 'godfather') }\end{array}$ & $\begin{array}{l}\text { root decides } \\
\text { [kubáros] }\end{array}$ & $\begin{array}{l}\text { root decides } \\
\text { [kubáru] }\end{array}$ \\
\hline $\begin{array}{l}\text { Marked (postaccenting) root } \\
\text { (/uran } \square \text { /- 'sky') }\end{array}$ & $\begin{array}{l}\text { root decides } \\
\text { [uranós] }\end{array}$ & $\begin{array}{l}\text { root decides } \\
\text { [uranú] }\end{array}$ \\
\hline
\end{tabular}

In Revithiadou (1999)'s proposal, the effect is brought about by a family of (positional faithfulness) constraints which she calls HEADFAITH(LA) (where LA signifies lexical accent):

(17) HeadFaith(LA): A lexical accent sponsored by a morphological head in he input has a correspondent in the output (HEADMAX(LA)).

A lexical A lexical accent sponsored by a morphological head in the output has a correspondent in the input (HEADDep(LA)).

Obviously, this needs an implementation of the concept head: what we need, given the above is one in which a derivational suffix is a head, but an inflectional suffix is not. Summarizing the discussion so far, both nominal roots and nominal affixes may (but need not) be marked for stress. If a root and an inflectional suffix have conflicting demands, the root wins; underlying stress on inflection thus only shows up if the root is unspecified. Default stress is antepenultimate, and stress-avoiding morphemes trigger local stress (on adjacent syllables). Representation of preaccenting suffixes and postaccenting roots is still a bit mysterious (cf. section 4.1), but roots and affixes which are thus specified still satisfy the calculus of faithfulness constraint: a post-accenting root with a pre-accenting suffix will carry stress on the suffix, thus satisfying the requirements of the root. Given this knowledge, we can now move on to stress in verbs.

\section{Stress in the past tense}

\subsection{The puzzle}

As soon as we start studying the verbal domain, we notice that it is quite different from what we know about nouns. In particular, there are only two classes of verbs: those which have stress on the final vowel of the root, and those which have stress on the theme vowel in the present. We will refer to these as conjugations $A$ and $B$ respectively:

\begin{tabular}{|c|c|c|}
\hline & conjugatic & conj \\
\hline $1 S$ & aláz+o & aуap+á+o / aуap+ó \\
\hline $2 S$ & aláz+i+s & aуap+á+s \\
\hline $3 S$ & aláz+i & ayap+á / ayap-á-i \\
\hline $1 S$ & aláz+u+me & ayap + á + me \\
\hline $2 S$ & aláz $+e+$ te & ayap+á+te \\
\hline $3 S$ & aláz+u+n(e) & ayap $+a ́+n(e)$ \\
\hline
\end{tabular}

Conjugation A verbs have stress on the final syllable of the root; conjugation B verbs have stress on the theme vowel, or on the inflectional suffix if this has merged with the theme vowel (such as is the case in the first person singular Philippaki-Warburton, 1970, 1976; Babinjotis, 1972; Ralli, 2005). Furthermore, conjugation A - which is the largest and most productive category - lacks an overt theme vowel altogether.

This might be seen to indicate that the number of stress specifications for verbal roots is more limited than for nominal roots, or that somehow faithfulness is more important for nouns than for verbs (Smith, 2001). In other words, we might 
conclude from this that verbs somehow have a different kind of lexical specification from nouns. However, this is not the route we want to take, because we believe it is not explanatory in the end: we want to know why verbs behave different from nouns, not just postulate it. Rather, we will want to make the difference between nouns and verbs follow from a difference in nominal and verbal morphosyntax. I argue that whereas the former is restricted to the word domain, the latter is more phrasal: verbal 'affixes' (in particular, es) actually behave more like affixes. This gives them a stronger position in the hierarchy.

In this paper, I concentrate on the past tense paradigms which provide a few additional and very specific complications. All past tense forms in conjugation $A$, and nearly all of them in conjugation $B$, have antepenultimate stress. I repeat the relevant paradigms here $^{9}$ :

(1) yrafo 'I write'

\begin{tabular}{|c|c|c|}
\hline rresen & Imperfective & Aorist \\
\hline yráf-o & é-yraf- & é-yraps-a \\
\hline yráf-is & é- & s-es \\
\hline yráf-i & é-yraf-e & é-yraps-e \\
\hline yráf-ume & yráf-ame & yráps-ame \\
\hline yráf-ete & yráf-ate & yráps-ate \\
\hline yráf-un(e) & yráf-ane / é-yraf-an & yráps-ane / \\
\hline
\end{tabular}

Descriptively, the augment $e$ - shows up exactly in those contexts in which it is needed to provide for an antepenultimate syllable, viz. if the stem and the suffix are monosyllabic only. The first and second singular plural suffixes are bisyllabic, and hence make the augment superfluous. Furthermore, Modern Greek has an optional rule of e epenthesis after $-n$; if this vowel is epenthesized after the final $n$ of the third person plural suffix, the augment does not show up, but if there is no epenthesis at the end, there is augmentation at the beginning, since it is no longer necessary (the word will already have three syllables). One could wonder whether the augment is a morpheme or inserted for purely phonological reasons only; we will argue for the latter (see Philippaki-Warburton, 1970; Babinjotis, 1972; Ralli, 1988, 2003; Drachman and MalikoutiDrachman, 2001, for some representative examples). Notice that the phonetic identity of augment and epenthetic vowel is at least compatible with the idea that synchronically these two vowels are the same. Furthermore, if the root is longer than monosyllabic, the augment does not show up at all, apparently because the root itself already provides enough space:

\begin{tabular}{lll} 
ayorázo ‘I buy’ & \\
Present & Imperfective & Aorist \\
\hline ayoráz-o & ayóraz-a & ayóras-a \\
ayoráz-is & ayóraz-es & ayóras-es \\
ayoráz-i & ayóraz-e & ayóras-e \\
ayoráz-ume & ayoráz-ame & ayorás-ame \\
ayoráz-ete & ayoráz-ate & ayorás-ate \\
ayoráz-un(e) & ayoráz-ane / ayóraz-an & ayorás-ane / ayóras-an
\end{tabular}

There are several reasons why the past tense is problematic for the theory of morphology-prosody interaction laid out in section 2.2. First, (Past) Tense is an inflectional category, so it should not be able to overrule any underlying stress on the roots; but it clearly does.

Secondly, we are dealing here with an unusual type of preaccenting. The stress does not fall on any suffix, nor on the last syllable of the root, but on the antepenultimate syllable of the whole word, which is quite remote from any visible suffix. At first sight, it looks as if we are dealing with a case of "aggressive default", as if the past tense wipes out any underlying stress specifications to give the default. However, the surfacing 'augment' /e/- provides an argument that we are not dealing with just a default: the stress patterns on nouns show us that antepenultimate stress is a default only if the word has at least three syllables. For bisyllabic words, it seems more reasonable to say that default stress is on the penult. We seem to have a very strong requirement on antepenultimate stress.

One potential way out of this problem is to postulate a difference in grammar between nominal and verbal morphology. For instance, we might assume that stressed -e and zero are allomorphs of the Past Tense morpheme, which either are

\footnotetext{
${ }^{9}$ The system historically developed out of the Ancient Greek system in which there was a é, showing up everywhere in the most past tense paradigms: éluon, élues, élue, elúomen, elúete, éluon. Such a system is easier to describe than the Modern Greek counterpart: they simply have a e-, and default stress; similar paradigms are still found in some modern dialects (Dimitris Papazachariou, p.c.); see Spyropoulos and Revithiadou (2008) for some discussion.
} 
categorized differently (-e for bisyllabic roots and zero elsewhere) or are selected to satisfy criteria of surface wellformedness. Notice, however, that this would imply, first, an analysis in which verbal roots are different from nominal roots in that they are stressless, which is not very explanatory, as we argued above. Secondly, it would actually still not explain why the zero affix is also accompanied with antepenultimate stress. However, even if we are willing to make such a move, the difference between the two grammars should be minimal. Furthermore, Revithiadou (1999)'s claim is that root specifications should win over affix specifications universally, i.e. not just in Greek nouns and verbs, but in all morphological constructions, because headedness is the only relevant factor and morphological headedness presumably is the same in all cases. That definitely seems the theoretically more interesting option.

\subsection{Analysis}

We thus want to maintain the standard view of prosody-morphology interaction based on Greek nouns, we do not want to change any of our underlying assumptions, and we want to develop an analysis of Modern Greek Past Tense stress which is consistent with our current state of the theory.

I propose that the phonological exponence of the functional head Past Tense in Greek is a stress marker only, i.e. a segmentally empty foot, which occurs in a functional head preceding the stem. It takes the following phonological shape McCarthy and Prince (1986):

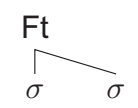

The phonological behaviour of this affix should follow from this special specification. It cannot be a normal inflectional affix, since it has the stronger ability to determine the stress of the whole structure. I therefore argue that it is a clitic, i.e. an independent head in the syntactic structure. As to the proclitic nature of this morpheme, I propose that also this follows from the syntactic structure.

A parallel with this may be the following. The epistemic marker $\theta a$ - which is also used to denote future tense - is an independent head (it clearly behaves as an independent function word) and it also precedes the verb: $\theta$ a yráfo 'I will write'. It is clear that the epistemic marker is in a different position in the syntactic tree, but I will argue that the positions are comparable.

We will now discuss the morphosyntactic and phonological aspects of this structure in turn.

\subsubsection{Morphosyntax}

The morphosyntactic structure of the Greek verbal morphology has been studied quite intensively, although many issues remain still open; see Tsimpli (1990), Rivero (1994), Drachman (1994), Philippaki-Warburton (1994), Rivero and Terzi (1995), Xydopoulos (1996), Philippaki-Warburton and Spyropoulos (1999), Philippaki-Warburton and Spyropoulos (2004), Roussou and Anna (2000), Alexiadou and Anagnostopoulou (2001), Galani (2002) for a few relevant studies; see also Spyropoulos and Revithiadou (2008) for a specific study of the morphology of the past tense, which is partly different from the one presented here. We will not go into all the fine-grained details, since many things remain to be sorted out, but before we enter the domain of past tense phrases, let us first consider a more transparent future tense phrase such as ðen fa yrapso 'I will not write'. In this phrase, ðen is a negative marker, Ta indicates future tense, grap 'write' is the verbal stem, -s- indicates [+ perfective] aspect, and $-O$ is an agreement marker for first person singular.

A straightforward way of putting this into a syntactic tree is the following:

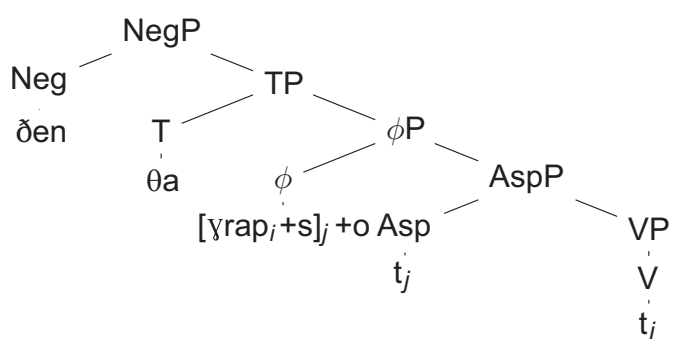

This structure assumes that aspectual features are the closest to the verbal stem, explaining by way of Baker (1988)'s Mirror Principle why the phonological exponent of aspect, $s$, ends up between the root and the agreement affix. Another 
assumption made here is that $\theta a$ is a tense marker. This is most probably too simplistic; Alexiadou and Anagnostopoulou (2001) (based on the work cited above; see also Joseph (2002b,a) for a different view) show that it actually behaves as a mood marker, expressing evidentiality and counterfactuality next to, or even instead of, future tense. This would indicate that in fact $\theta a$ and (past) tense are not in exactly the same head position. At the same time, it seems clear that mood and tense are very close to each other in their syntactic position as well as, we would claim, their phonological exponence.

In any case, it seems reasonable to assume that the projection of past tense is close to that of tha, and similar to it in morphosyntactic structure. Alexiadou and Anagnostopoulou (2001) provide a number of arguments why tha (as well as a few other mood markers such as na) should be considered as independent heads rather than as affixes. One of these arguments is that all these tense and mood markers behave as more independent units from the root. Another argument is that these markers occur on the lefthand side of the root, whereas all inflectional affixes occur on the right. It thus seems that the elements on the lefthand side are more independent than those on the righthand side. We may formalize this by stating that the element on the left are (pro)clitics, whereas those on the right are suffixes.

If we apply these arguments to (past) tense just as well as to (evidential) mood, we get the following representation for the aorist form agorases 'you bought':

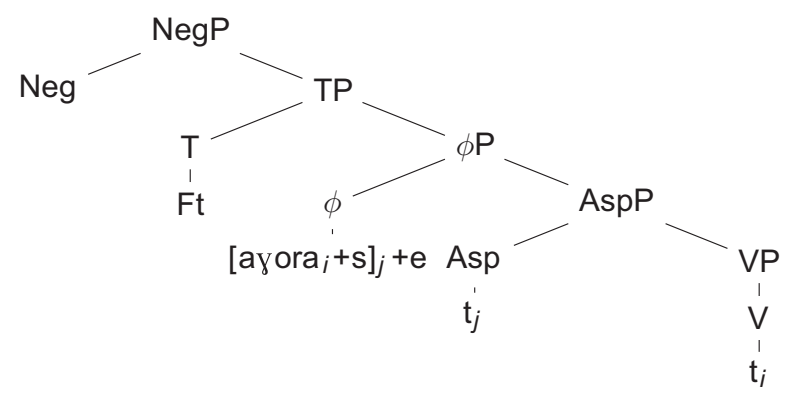

At the end of the syntactic derivation, we thus have a stress marker immediately preceding the verbal stem. Like the mood marker tha, it is not a morphological affix, but an independent head preceding the verbal root, which has moved up to Asp. Phonetically, this is an uninterpretable structure - we cannot pronounce a foot without segmental content; it is the task of phonology to produce a reasonable interpretation of this output of the syntax.

\subsubsection{The phonology of empty procliticized feet}

One problem we had incorporating the past tense data in our overall picture of Modern Greek word stress, has already been solved by now: tense markers are no affixes in Greek, but free-standing heads procliticizing to the root. Past tense thus is a proclitic, and a head; as a matter of fact, $\mathrm{T}$ is arguably the head over the whole construction in (22), so that its stress markings will win over those of the verb. ${ }^{10}$

In order to mirror the syntactic order, we the empty $\mathrm{Ft}$ to the word also in the phonology. A standard way of getting such an effect is by way of an ALIGN constraint (McCarthy et al., 1993): ${ }^{11}$

(23) ALIGN- $\left(X^{0}, L, \omega, L\right)$ : If a syntactic head $H^{1}$ precedes another head $\mathrm{H}^{2}$ in the constituent, the exponence of $\mathrm{H}^{1}$ should not follow the exponence of $\mathrm{H}^{2}$ in the phonological word.

This constraint will in this case enforce the Tense, i.e. the floating foot to be as much to the left as possible; given the undominated status of the three syllable window, this will mean that stress prefers to end up at the left edge of that window, in other words on the antepenultimate syllable. This is the reason why total alignment is blocked in in *[áyorasa] (or *[ $\theta^{a}$ ayoraza], and why we find [ayórasa] instead: $3 \sigma \gg$ ALIGN. But now a new question presents itself: why do we then have [ayórasa], and not [ayorása] or [ayorasá]?

One possible answer to this question is that ALIGN is gradient, and still prefers stress as close to the left edge of the word as possible. Serious objections have been raised against the gradient interpretation of constraints, however (McCarthy, 2003).

\footnotetext{
${ }^{10}$ Assuming that all tenses are heads in this way, and have some stress specification, may help us set one step in the direction of an understanding why there is so little differentiation between Greek verbal stems.

${ }^{11}$ Kayne (1994) holds that syntactic phrases do not have the property of linearity, but that syntactic c-command relations are to be translated into phonological linearity. Adopting this idea would lead to a slightly more complex formulation of this constraint.
} 
We actually get the right result also under a categorical interpretation of ALIGN, since antepenultimate stress is the default, as we have seen:

a. $3 \sigma \gg$ ALIGN-TENSE,NONFIN

b. Ft+ayora+s+a $3 \sigma \quad$ ALIGN-Tense NONFIN

\begin{tabular}{lllllll}
\hline \multicolumn{1}{c}{ ayórasa } & \multicolumn{4}{c}{1} \\
\hline a. $\sim$ áyorasa & 1 & W & 0 & L & & \\
\hline b. $\sim$ ayorása & & 1 & & 1 & W \\
\hline c. $\sim$ ayorasá & & 1 & & 1 & W \\
\hline
\end{tabular}

Antepenultimate stress thus really functions as the default; it gets realized where it does because the foot is underlyingly floating and faithfulness have no power over it. Notice also that we assume that it is still the underlying foot of the Past Tense which is realized as the stress. This is in some sense abstract: one cannot 'hear' whether a stress belongs to the past tense, or to the verb, or has been added for purely phonological reasons. It is the analysis which makes us decide for the former option here.

Given the fact that the past tense stress functions as default, we have to wonder why we need epenthesis of the augment in [ékana], since *[kána] satisfies this constraint equally well. Notice, however, that in the latter case, the precedence relations between Tense and the verb, which are present in the syntax, are no longer preserved. One of the functions of phonological structure is to reflect morphological structure (van Oostendorp, 2004); therefore, it is preferable if two morphemes have their own independent phonological exponence. This can be expressed again in terms of an alignment constraint:

(25) a. UNIQUEEXPONENCE: Every morpheme should have a unique exponence in the phonology.

b. DEP: No epenthesis (of vowels)

\begin{tabular}{|c|c|c|c|c|c|}
\hline$F t+$ kan $+a$ & $3 \sigma$ & & UNIQUE & $\mathrm{D}$ & \\
\hline (é)(kana) & & & & & 1 \\
\hline a. $\sim$ (éte)(kana) & & W & & 3 & W \\
\hline b. $\sim$ (kána) & & & $1 \quad W$ & 0 & $\mathrm{~L}$ \\
\hline c. $\sim$ (kaná) & & & $1 \mathrm{~W}$ & 0 & $\mathrm{~L}$ \\
\hline
\end{tabular}

According to UNIQUE, a good realisation of the past tense head would be a complete empty foot with all material epenthetic, e.g. ete: both morphemes would then end with their own binary foot. However, such a stress placement would never be able to surface. Stems are at least monosyllabic, as are suffixes. ing a bisyllabic unit before this would result in preantepenultimate stress, which is not an option given the inviolability of $3 \sigma$; furthermore, such a completely inserted binary foot would lead to unnecessarily many violations of the Dep constraint. We can thus only realize the empty head of a monosyllabic foot and fill it with the augment; we know that such a foot is possible in Greek, since the language has words ending in a stressed syllable. This results in a relatively well-aligned structure, even if it comes at the cost of minimal violation of DEP.

This line of reasoning leads us to conclude that UNIQUE would prefer augmentation also in other cases (e-agoras-a, e-kaname), but here it will always result in a violation of $3 \sigma$ :

\begin{tabular}{|c|c|c|c|c|c|}
\hline $\mathrm{Ft}+\mathrm{kan}+$ ame & $3 \sigma$ & UNIQUE & DEF & & NonFIN \\
\hline káname & & 1 & & & \\
\hline a. ékaname & $1 \mathrm{~W}$ & & 1 & W & \\
\hline b. ekáname & & 1 & 1 & W & \\
\hline c. $\sim$ kanáme & & 1 & & & $1 \mathrm{~W}$ \\
\hline
\end{tabular}


The form in (27a) is well-aligned, since the proclitic really precedes the stem, but it does this at the cost of violating the inviolable three syllable window. (27b) has an augment and escapes the constraint $3 \sigma$ by shifting the stress, but that means that the augment no longer helps avoiding a violation of ALIGN-M, so that it is obsolete. (27c) gives yet another example with stress occurring in a non-underlying non-antepenultimate position; such forms never win. Thus the unaugmented form with antepenultimate stress wins in all these cases.

A final issue is of course in what sense the fact that the foot is a proclitic rather than a should be phonologically relevant. We have seen that there is a difference between inflectional and derivational suffixes in Modern Greek: the latter behave as heads and can impose their stress pattern, whereas the former cannot. This is due to a constraint HEADFAITH(LA). Since clitics are independent units in the syntactic trees, it makes sense to say that they are heads as well as derivational affixes are. The fact that they therefore impose lexical stress, should not come as a surprise.

This concludes our analysis of past tense stress. We see that the behaviour does not really contradict the tenets of the standard theory on Modern Greek stress which was developed on the basis of nouns; rather it adds to this theory by taking into account other morphosyntactic configurations, in particular one in which there is no syntactic adjunction, but rather an independent head. It also takes into account a new type of structure, viz. an empty foot. These assumptions still leave several questions open, some of which will be addressed in the next section.

\section{Further issues}

\subsection{Stress avoidance}

In this paper, we have so far glossed over the existence of stress-avoiding morphemes. These come in two types: postaccenting roots and pre-accenting suffixes. What these have in common is that stress is determined by the morpheme in question, but it is not realized on that particular morpheme:

$$
\begin{aligned}
& \text { a. post-accenting root: uranós (cf. ánthropos) }
\end{aligned}
$$

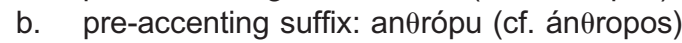

The issue is how exactly we should represent these accentual properties. One desideratum is that such a representation should not be using any morphological diacritics; another is that it should explain why roots are postaccenting, and suffixes are pre-accenting.

It seems reasonable to assume that stress-avoiding affixes are represented by floating stress markers: they do have stress, but this floats to a different morpheme. This now leads us to the issue of whether this stress marking is to be represented as an accent or as a foot (compare the discussion below (9a) on page 6).

Revithiadou (2007) analyses stress avoidance in terms of a floating accent. The accent belongs to a morpheme (e.g. a 'post-accenting' root), but there is no association line between the accent and any vowel of the morpheme. The issue now is why this floating accent should be linked outside the morpheme to which it belongs: if it is part of a suffix, why cannot it be linked to a suffix vowel?

We could follow a proposal to introduce constraints of the following type (cf. van Oostendorp, 2007):

$$
\text { Strict Alternation (SA): Association lines which could be underlying, must be underlying. }
$$

van Oostendorp (2007) gives a formalisation of such constraints in terms of his theory of morphological colours. The idea is that every feature, association line, etc., of a morpheme has an underlying marking to the effect that it belongs to this morpheme (every morpheme has a 'colour' and each part of the phonological representation shares that colour). Gen can only insert association lines without a colour. SA then says: if a feature and a host of a feature belong to the same morpheme, only (see also Trommer (2011)), they can only be connected by an association line which belongs to that morpheme as well.

SA constraints may be independently needed to deal with derived environment effects. For instance, it has been claimed that Korean high front vowels trigger palatalisation on a preceding coronal plosive, as is illustrated in (30b). This rule only applies across morpheme boundaries however; it does not apply in the form in (30c), where the /t/ and /i/ are already adjacent at the underlying level (Iverson, 1993; Polgárdi, 1998; Rhee, 2002, to mention just a few recent sources).

$$
\begin{aligned}
& \text { a. } \quad \mathrm{t}, \mathrm{t}^{h} \rightarrow \mathfrak{t}, \mathrm{tg}^{h} /{ }^{\mathrm{i}} \\
& \text { b. hæ tot }+\mathrm{i} \rightarrow \text { hæ dodzi 'sunrise-Nom' } \\
& \text { c. mati } \rightarrow \text { madi 'knot' }
\end{aligned}
$$

What is the reason for this difference? SA provides an answer to that question. Let us assume that palatalisation is a form of assimilation: some of [i]'s features spread to the plosive, changing it into a palatal. SA prevents these new 
association lines in the case of (30c), but it does not do so in the case of (30b). In essence it prevents association between a feature and a segment when they belong to the same morpheme.

Given this line of argument, floating feet (with underlying moras) could also be subject to this constraint:

SA- $\mu$ : Association lines between mora's and segments which could be underlying, must be underlying.

When we thus have an input with a floating foot, built on a floating head mora, SA- $\mu$ does not allow us to build a foot on top of any of the vowels which belong to the same morpheme, but we can build it on top of a morpheme which is close enough. In the following pictures, subscripts denote morphological identity:

SA at work

input incorrect output correct output

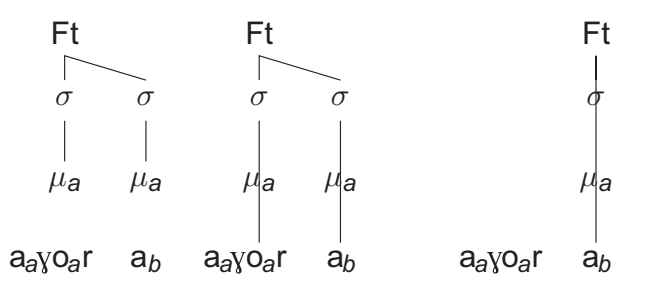

On the other hand, non-floating underlying feet are not affected by having a high-ranking constraint SA, and they can stay in their own position. The reason why suffixal stress avoidance is expressed as pre-accenting and root stress avoidance is post-accenting should have something to do with this.

Notice that this analysis makes crucial use of a floating foot, giving independent support for our analysis of past tense: if there are affixes which have segmental content and a floating foot, there should also be morphemes which consist of a floating foot only. Notice that SA is irrelevant for a purely floating foot, such as is represented by the past tense, since there is no segment at all it could connect to, at least assuming that the augment is not morphological but the result of purely phonological epenthesis, as we have done so far.

\subsection{Interaction with particles}

We next turn our attention to the interaction of other particles with past tense stress. It has been noted that some particles seem to be able to carry the past tense 'antepenultimate' stress; in this case the augment does not surface (Kaisse, 1976; Alexiadou and Anagnostopoulou, 2001). The process is optional: it is also possible to have the augment carry the stress (33a). In this sense these particles behave like clitics (33c). Other particles do not seem subject to the same process: they never carry stress, and the augment is always there (33b).

a. $\quad \theta a$ é-perna - tá perna 'I would take', na é-perna - ná perna 'that I take'

b. ðen é-perne - `ðén perne 'I do not take' (`é perne), as é-perne - *ás perne 'that I take'

c. to é-perna - tó perna 'I take it'

There clearly are two varieties of Greek, one in which the augment always occurs, and one in which it occurs after the particles in (33b), but not after those in (33a). (All speakers may be in command of both varieties; there is intraspeaker variation.)

I propose that the relevant difference between (33a) and (33b) is between consonant-final and vowel-final particles. Epenthesis can be blocked when it leads to hiatus. Hiatus avoidance is a more general process in Greek phonology, and in many cases it is optional (see Nespor and Vogel, 1986; Condoravdi, 1990; Arvaniti and Pelekanou, 2002; Kainada, 2007, and references cited there). We assume that this variability is due to the fact that the relevant constraints are unranked in Greek grammar (Anttila, 1997, 2002, 2007). For instance, let us assume that the relevant constraints are NoHIATUS and MaX:

\begin{tabular}{lll}
\hline mu+aresi & NoHiatus & MAX \\
\hline a. maresi & & * \\
\hline b. mu aresi & * & \\
\hline
\end{tabular}


Since no ranking is preestablished, we sometimes get deletion (NoHIATUS $\gg$ MAX) and sometimes no deletion (MAX》NoHIATUS).

The actual analysis will be more complicated. In the first place, we know that syntactic and/or prosodic boundaries influence the chance that a hiatus is resolved by deletion. Further, the issue of course would have to be resolved which of the two vowels gets deleted in the hiatus context (Casali, 1998, 2011). For Greek phonology, it is usually assumed that a sonority hierarchy is responsible, of (roughly) the structure $i \prec e \prec u \prec 0 \prec a$ (Holton et al., 2006; Revithiadou et al., 2006). The least sonorous of two vowels in a sequence will be deleted. This presumably explains for instance why it is the first (clitic) vowel which is deleted in mou aresi 'I like it' [maresi]: $u$ is weaker than a.

Given our analysis so far, something else should be going on in the cases in (33), however. Since the augment is not underlying, it cannot be subject to any constraints against deletion such as MAX. In this case, the relevant (violated) constraint turns out to be ALIGN-M. If a foot is placed on the clitic, the boundary between clitic and word is blurred, giving a violation of Alignment:

\begin{tabular}{|c|c|c|}
\hline$\theta a+$ perna & NoHiatus & ALIGN-M \\
\hline a. $\theta a ́$ perna & & * \\
\hline b. $\theta a$ éperna & * & \\
\hline
\end{tabular}

A word needs to be said about es. Consider an example such as /andi-yrafo/ 'I copy' $\rightarrow$ [andéyrapsa] 'I copied'. Notice that in this case, it looks as if the underlying vowel is deleted; similar examples are antédrasa 'I reacted' (from anti and edrasa) and parédosa 'I delivered' (from para and edosa). The latter example even shows a reversal from the sonority hierarchy. Yet another difference from known instances of hiatus resolution, is that the process seems obligatory in this case.

However, we are dealing in all these cases with 'derivational processes of learned origin' as Holton et al. (2006:22) note, so that it is not clear we are necessarily dealing with productive phonology here at all. Similar 'unusual' hiatus resolutions are also found in other tenses of verbs with a similar learned background, as words such as katéxo 'I possess' (from kata and exo, again with sonority reversal) and epérxete 'it is coming' (from epi and erxete) testify.

\subsection{A few exceptions}

In this section, we will deal with three groups of apparent exceptions to the generalisation that past tense is expressed by antepenultimate stress.

The first class of exceptions consists of forms such as vika 'I went out' [v'íka] (from /v'éno/), iha 'I had' [íxa] (from /exo/), bika 'I went in' [bíka] (from /béno/), ixera 'I knew' [íksera] (from /kséro/). Synchronically, this is a closed class of irregular and fossilized forms, which are not formed with a separate morpheme, but by root allomorphy (as in the case of English go-went). They therefore do not form real exceptions to our claims as to the structure of the regular past tense (Spyropoulos and Revithiadou, 2008).

Because perfect forms are formed with the verb eho 'have', pluperfect paradigms (which are past tense) are all expressed in this quasi-irregular way:
íxa ðiavási 'I had read'
íxes ðiavási 'you had read'
íxame ðiavási 'we had read'
íxe ðiavási 'he/she had read'
íxate Jiavási 'you had read'
íxan ðiavási 'they had read'

A third class of apparent exceptions concerns the active imperfective of conjugation B verbs: / ayapáo/ 'I love' $\rightarrow$ [ayapúsa] 'I was loving' rather than *[ayápusa].

It is probably important that conjugation B involves those verbs which have a theme vowel, which is furthermore stressed in other tenses (like the present tense). This stressed theme vowel can sometimes be deleted, in which case stress shifts rightward: /ayapáo/ 'I love' $\rightarrow$ [ayapó]. ${ }^{12}$

If we assume theme vowel deletion is also going on here, accompanied by a similar type of rightward stress, we have a case of 'opaque antepenultimate stress': /ayapáusa/ $\rightarrow$ [ayapúsa]. This poses a problem for an OT analysis, albeit one

\footnotetext{
${ }^{12}$ Theme vowel deletion involves yet another kind of 'hiatus resolution', different from the ones we have seen in section 4.2 . In this case, it is actually always the theme vowel /a/ which gets deleted, in violation of sonority requirements, but possibly triggered by the fact that the theme vowel is morphologically less prominent (reveals less crucial information) than the inflectional vowel.
} 
which is familiar to any scholar working on that theory: the relevant constraint seems to operate on a representation which is different from the actual surface form. It can be solved by whatever mechanism one considers to be relevant, such as Stratal Optimality Theory (Kiparsky, 2006) or Harmonic Serialism (McCarthy, 2000, 2008).

I leave this open for further research, although a few remarks are in order. In the first place, it should be noted that stress is also on the inflectional vowel in cases like [ayapúsame]. This cannot follow from an intermediate form layapáusame/, since such a form would violate the three syllable window. However, in such a case, stress shift would take place, so that the underlying form would be /ayapaúsame/, and after deletion of the theme vowel, we would still end up with the required form.

In the second place, other past tense forms of Conjugation B are not opaque in the same way (e.g. the perfective past form ayápisa or the imperfective ayápaya). It obviously needs to be sorted out why in this case the stress is transparent; possibly a difference between the two types of inflection plays a role here.

\subsection{Compound verbs}

One complication arises in the case of compound verbs. In these cases we find some variation as to the presence or absence of the augment:

(37) a. ksana-éyrapsa / ksanáyrapsa 'I wrote again' (with ksana 'again'

b. $\quad \theta a$ to ksana-éyrafa / $\theta a$ to ksaná-yrafa 'I would have written it'

c. ( $(\theta$ a to) e-ksanayrafa 'I wrote again'

(38) a. para-éyrapsa / paraáyrapsa 'I wrote a lot' (with para 'a lot')

b. $\quad \theta a$ to para-éyrafa / $\theta$ a to pará-yrafa 'I would have written it a lot'

c. ( $\theta$ a to) e-parayrafa 'I wrote a lot'

An anonymous referee points out that these examples can be seen as problems, since they show that e can appear between the two parts of a compound, while bona fide proclitics like $\theta$ a cannot, as (37b) and (38b) show. Notice however, that in our analysis e is not a proclitic; the stress is. Since this foot can only be realized on a three syllable window, (37c) and $(37 \mathrm{c})$ are excluded.

The real question then is what accounts for the variation between the forms in (37a) and (38a). The problematic cases are the ones where the augment shows up right in the middle of the word: ksana-éyrapsa, para-éyrapsa; the forms ksanáyrapsa, pará-yrapsa (which are available to all Greek speakers as well) pose no such problems, the augment just is not needed.

One suggestion is that in the grammar in which the augment shows up, there is an extra restriction that stress should not show up on the, if it can be avoided. This is obviously yet another instance of the phonology mirroring the morphosyntactic structure: since the es are no heads, it is preferable that they are not stressed. An alternative possibility is that the grammar generating the augment in these cases disallows trochaic feet which would span the boundary between and stem (Ito and Mester (1999)'s CRISPEDGE constraint).

\section{Conclusions}

The (past tense) verbal system of stress-morphology interaction seems different from the nominal system in Modern Greek. The crucial difference is that in the verbal system we have an inflectional morpheme which is an empty foot proclitic. The proclitic status is independently motivated in Greek morphosyntax, and the present paper thus provides an argument in a debate on phonological differences between nouns and verbs (Smith and Jennifer, 2011).

The representation of the proclitic is like that of a stress avoiding morpheme, except that it does not have any segments. Such an input is predicted to exist given Richness of the Base, and its behaviour is predicted by the standard theory of Greek stress as it has been developed on the basis of nominal stress. This shows that the two systems are indeed a unity, their superficial differences being due to differences in syntactic structure (verbal 'affixes' can be independent heads) as well as phonological exponence (the past tense happens to be realised as an empty-headed foot).

Of course, many other topics are open for research. One of them is how we can account for the stress pattern in other parts of the Modern Greek verbal paradigm. What explains for instance the two conjugations in (18)? Why do verbs with an overt theme vowel behave differently from those without a theme vowel in the present tense? Similarly, where do adjectives and other lexical categories fit into the overall picture which is now emerging for Greek stress? Can their behaviour be similarly explained in terms of their syntactic status? 


\section{References}

Alexiadou, A., Anagnostopoulou, E., 2001. Syntactic Adjacency as a Condition on Phases. Handout of a presentation given at GLOW, Braga. Anttila, A., 1997. Variation in Finnish Phonology and Morphology. Ph.D. Thesis. Stanford University.

Anttila, A., 2002. Variation and phonological theory. In: Chambers, J., Trudgill, P., Schilling-Estes, N. (Eds.), The Handbook of Language Variation and Change. Blackwell, Oxford, pp. 206-243.

Anttila, A., 2007. Variation and optionality. In: de Lacy, P. (Ed.), The Cambridge Handbook of Phonology. Cambridge University Press, Cambridge, MA, pp. 519-536.

Apoussidou, D., 2003. The deformity of anti-faithfulness. In: Spenader, J., Eriksson, E., Dahl, O. (Eds.), Proceedings of the Stockholm Workshop on Variation within Optimality Theory, pp. 15-24. URL http://uvafon.hum.uva.nl/diana/papers/TheAntiFaithfulness.pdf.

Arvaniti, A., Pelekanou, T., 2002. Postlexical rules and gestural overlap in a Greek spoken corpus. Recherches en linguistique grecque 1, 71-74. URL http://ling.ucsd.edu/arvaniti/Pelekanou\&Arvaniti.pdf.

Babinjotis, G., 1972. Ta Rima tis Ellinikis. Idrima Sofias Saripolou.

Baker, M., 1988. Incorporation: A Theory of Grammatical Function Changing. University of Chicago Press, Chicago.

Burzio, L., Tantalou, N., 2006. Modern Greek Accent and Faithfulness Constraints in OT. Johns Hopkins University (Manuscript).

Casali, R., 1998. Resolving Hiatus. Outstanding Dissertations in Linguistics. Garland, New York and London.

Casali, R., 2011. Hiatus resolution. In: van Oostendorp, M., Ewen, C.J., Hume, E., Rice, K. (Eds.), The Blackwell Companion to Phonology, vol. III. Wiley-Blackwell, Oxford, UK, (Chap. 61), pp. 1434-1460.

Condoravdi, C., 1990. Sandhi rules of Greek and prosodic theory. In: Inkelas, S., Zec, D. (Eds.), The Phonology-Syntax Connection. The University of Chicago Press, Chicago and London, (Chap. 4), pp. 63-84.

Drachman, G., G.Drachman1994. Verb movement and minimal clauses. In: Philippaki-Warburton, I., Nikolaidis, K., Sifianou, M. (Eds.), Themes in Greek Linguistics: Papers from the First International Conference on Greek Linguistics. John BenjaminsAmsterdam and Philadelphia pp. $45-52$

Drachman, G., Malikouti-Drachman, A., 1999. Greek word accent. In: van der Hulst, H. (Ed.), Word Prosodic Systems in the Languages of Europe. Mouton De Gruyter, Berlin/New York, pp. 897-945.

Drachman, G., Malikouti-Drachman, A., 2001. Concrete morphology, affix typology and concord chains. In: Ralli, A., Joseph, B., Janse, M. (Eds.), Proceedings of the First Conference of Modern Greek Dialects and Linguistic Theory. University of Patras, Patras, pp. 51-65.

Galani, A., 2002. A DM Analysis of the Augment in Modern Greek. University of York (Manuscript).

Hockett, C., 1958. Two models of grammatical description. Word 10, 210-231.

Holton, D., Mackridge, P., Philippaki-Warburton, I., 2006. Greek. A Comprehensive Grammar of the Modern Language. Routledge Comprehensive Grammars. Routledge, London and New York.

Ito, J., Mester, A., 1999. Realignment. In: Kager, R., van der Hulst, H., Zonneveld, W. (Eds.), Prosody-Morphology Interface. Cambridge University Press, Cambridge, UK, pp. 188-217.

Iverson, G., 1993. (Post) lexical rule application. In: Hargus, S., Kaisse, E. (Eds.), Studies in Lexical Phonology, vol. 4. Academic Press, San Diego, pp. 255-275.

Joseph, B., 2002a. Defining 'Word' in Modern Greek: a response to Philippaki-Warburton and Spyropoulos 1999. In: Booij, G., van Marle, J. (Eds.), Yearbook of Morphology 2001. Kluwer Academic Publishers, pp. 87-114.

Joseph, B., 2002b. 'Word' in Modern Greek. In: Dixon, R.M.W., Aikhenvald, A.Y. (Eds.), Word: A Cross-Linguistic Typology. Cambridge University Press, pp. 243-265.

Kainada, E., 2007. Prosodic boundary effects on durations and vowel hiatus in Modern Greek. In: Proceedings of ICPhS 2007. pp. 1225-1228. URL http://www.icphs2007.de/conference/Papers/1484/1484.pdf.

Kaisse, E., 1976. Stress melodies and a fast speech rule in Modern Greek. NELS 6, 165-175.

Kayne, R.S., 1994. The Antisymmetry of Syntax. The MIT Press, Cambridge, Linguistic Inquiry Monograph Twenty-Five.

Kiparsky, P., 2006. Paradigms and Opacity. CSLI, Stanford.

Malikouti-Drachman, A., Drachman, G., 1989. Stress in Greek. In: Studies in Greek Linguistics 1989. Aristotle University of Thessaloniki, pp. 127143.

McCarthy, J., 2003. OT constraints are categorical. Phonology 20, 75-138.

McCarthy, J.J., 2000. Harmonic serialism and parallelism. In: Hirotani, Masako, (Eds.), Proceedings of the North Eastern Linguistics Society, vol. 30. Amherst, MA, pp. 501-524.

McCarthy, J.J., 2008. The gradual path to cluster simplification. Phonology 25, 271-319.

McCarthy, J.J., Prince, A., 1986. Prosodic Morphology. Tech. Rep. Rutgers University Center for Cognitive Science.

McCarthy, J.J., Prince, A., 1993. Generalized alignment. In: Morphology Yearbook, pp. 79-153. URL http://scholarworks.umass.edu/linguistfacultypubs $/ 100 /$

Melvold, J.L., 1990. Structure and Stress in the Phonology of Russian. Ph.D. Thesis. MIT.

Nespor, M., Ralli, A., 1994. Stress domains in Greek compounds: a case of morphology-phonology interaction. In: Philippaki-Warburton, I., Nikolaidis, K., Sifianou, M. (Eds.), Themes in Greek Linguistics. John Benjamins, pp. 201-208.

Nespor, M., Ralli, A., 1996. Morphology-phonology interface: phonological domains in Greek compounds. The Linguistic Review 357-382

Nespor, M., Vogel, I., 1986. Prosodic Phonology. Foris, Dordrecht.

Nikolou, K., 2005. Nominal Compounding in Greek: A Case of Morphology-Phonology Interaction. University of the Aegean (Manuscript).

van Oostendorp, M., 2004. Crossing morpheme boundaries in Dutch. Lingua 114 (11), 1367-1400.

van Oostendorp, M., 2007. Derived environment effects and consistency of exponence. In: Blaho, S., Bye, P., Krämer, M. (Eds.), Freedom of Analysis? Mouton de Gruyter, Berlin, pp. 123-148.

Philippaki-Warburton, I., 1970. On the Verb in Modern Greek. The Hague, Mouton.

Philippaki-Warburton, I., 1976. On the boundaries of morphology and phonology. A case study from Modern Greek. Journal of Linguistics 12, 259-278. 
Philippaki-Warburton, I., 1994. The subjunctive mood and the syntactic status of the particle na in Modern Greek. Folia Linguistica (Acta Societatis Linguisticae Europaeae) 28, 297-328.

Philippaki-Warburton, I., Spyropoulos, V., 1999. On the boundaries of inflection and syntax: Greek pronominal clitics and particles. In: Booij, Geert, Jaap van Marle, (Eds.), Yearbook of Morphology 1998. Kluwer Academic Publishers, pp. 45-72.

Philippaki-Warburton, I., Spyropoulos, V., 2004. A change of mood: the development of the Greek mood system. Linguistics 42, $791-817$.

Polgárdi, K., 1998. Vowel Harmony. An Account in Terms of Government and Optimalityu Theory. Ph.D. Thesis. Leiden University.

Protopapas, A., Gerakaki, S., Alexandri, S., 2006. Lexical and default stress assignment in reading Greek. Journal for Research in Reading 29 (4), 418-432.

Ralli, A., 1988. Eléments de la morphologie du grec moderne: La structure du verb. Ph.D. Thesis. Université de Montréal.

Ralli, A., 2003. Morphology in Greek linguistics: the state of the art. Journal of Greek Linguistics 4, 77-129.

Ralli, A., 1997. Compounds in Modern Greek. Rivista di Linguistica 4 (1), 143-174.

Ralli, A., 2005. Morfología. Patakis, Athina.

Revithiadou, A., 1997. Prosodic domains in Greek compounding. In: Malikouti-Drachman, A., Fykias, J., Klidi, C. (Eds.), Proceedings of the 2nd International Conference on Greek Linguistics. University of Salzburg, pp. 107-116.

Revithiadou, A., 1999. Headmost Accent Wins: Head Dominance and Ideal Prosodic Form in Lexical Accent Systems. Ph.D. Thesis. University of Leiden.

Revithiadou, A., 2007. Colored turbid accents and containment: a case study from lexical stress. In: Blaho, S., Bye, P., Krämer, M. (Eds.), Freedom of Analysis? Mouton De Gruyter, Berlin, pp. 149-174.

Revithiadou, A., van Oostendorp, M., Nikolou, K., Tiliopoulou, M.-A., 2006. Vowel-harmony in contact-induced systems. The case of Cappadocian and Silly. In: Janse, M., Joseph, B., Ralli, A. (Eds.), Proceedings of the 2nd International Conference on Modern Greek Dialects and Linguistic Theory. University of Patras, Patras.

Rhee, S.J., 2002. Empty Nuclei in Korean. Ph.D. Thesis. University of Leiden.

Rivero, M.-L., 1994. Clause structure and V-movement in the languages of the Balkans. Natural Language and Linguistic Theory 12, 63-120.

Rivero, M.-L., Terzi, A., 1995. Imperatives, V-movement and logical mood. Journal of Linguistics 31, 301-332.

Roussou, A., 2000. On the left periphery: modal particles and complementizers. Journal of Greek Linguistics 1, 65-94.

Selkirk, L., 1982. The Syntax of Words. The MIT Press, Cambridge, MA.

Smith, J., 2001. Lexical category and phonological contrast. In: Kirchner, R., Pater, J., Wikely, W. (Eds.), Papers in Experimental and Theoretical Linguistics 6: Workshop on the Lexicon in Phonetics and Phonology. University of Alberta, Edmonton, pp. 61-72.

Smith, J., 2011. Category-specific effects. In: van Oostendorp, M., Ewen, C.J., Hume, E., Rice, K. (Eds.), The Blackwell Companion to Phonology, vol. IV. Blackwell-Wiley, London, pp. 2439-2463.

Spyropoulos, V., Revithiadou, A., 2008. The morphology of past in Greek. In: Stavrou, M., Papadopoulou, D., Theodoropoulou, M. (Eds.), Proceedings of the 29th Annual Meeting of Greek Linguistics. Department of Linguistics, Aristotle University of Thessaloniki, pp. 108-122. URL http://www.revithiadou.gr/files/papers/Themorphologyofpast.pdf.

Trommer, J., 2011. Phonological Aspects of Western Nilotic Mutation Morphology. Universität Leipzig, Habilitationsschrift.

Tsimpli, I.-M., 1990. The clause structure and word-order in Modern Greek. UCL Working Papers in Linguistics 2, $226-255$.

Xydopoulos, G., 1996. Tense, Aspect, and Adverbials in Modern Greek. Ph.D. Thesis. University College London. 